\title{
Accuracy of abdominal radiography to determine fetus numbers in bitches at two gestational ages
}

\section{Acurácia da radiografia abdominal na determinação do número de fetos de cadelas em duas idades gestacionais}

\author{
Daniela Aparecida Ayres Garcia ${ }^{1 *}$; Mariana Regina Rompkovski²; \\ Elaine Mayumi Ueno Gil ${ }^{1}$; Amália Turner Giannico ${ }^{1}$; Tilde Rodrigues Froes ${ }^{3}$
}

\begin{abstract}
Abdominal radiography is considered the most accurate technique for determining fetal numbers. Nevertheless, there is a disagreement in the literature concerning the optimal time to perform the examination to obtain the most accurate fetal count. The objective of this study was to compare the accuracy of fetal counting in bitches at two gestational stages, using digital radiographs, and to analyze the possible complicating factors. Fifty-eight abdominal radiographs of 38 bitches at two gestational stages were analyzed by two observers. The first stage (Group I) included bitches between 45 and 48 days of gestation, and the second (Group II) bitches between 54 and 57 days of gestation. The Kappa index of agreement for categorical data indicated agreement between observers. Agreement was lower for Group I than for Group II. The estimated value of Pearson's coefficient for Group I was positive but weak for correlation between observers 1 and 2 and the number of puppies born. There was significant correlation between counts and the number of puppies born in Group II. We conclude that radiographic examination is not an accurate method of determining fetal number between 45 and 48 days of gestation and that the optimal time to perform this examination is between 54 and 57 days of gestation, at which time the fetal skull is fully visible on radiographs.
\end{abstract}

Key words: Dog, fetal count, pregnancy, radiographic examination

\section{Resumo}

A radiografia de abdome é considerada a técnica mais precisa para a contagem do número de fetos. No entanto, há discordância na literatura sobre o momento ideal para realizar o exame para obter a contagem fetal mais precisa. Os objetivos deste estudo foram comparar, em dois períodos de gestação, a precisão da contagem fetal em cadelas a partir de radiografias digitais e analisar os possíveis fatores complicadores. Foram realizadas 58 radiografias abdominais de 38 cadelas analisadas por dois observadores em duas fases da gestação. A primeira fase (Grupo I) incluiu cadelas entre 45 e 48 dias de gestação, e a segunda (Grupo II) cadelas entre 54 e 57 dias de gestação. O índice de concordância Kappa para dados categóricos indicaram concordância entre os observadores. Não obstante, o acordo entre os observadores foi menor no Grupo I do que no Grupo II. O valor estimado do coeficiente de Pearson para o Grupo I foi fraco e positivo para a correlação entre o observador 1 e 2 e o número de filhotes nascidos. No Grupo II, houve correlação significativa entre a contagem e o número de filhotes nascidos. Conclui-se que o exame radiográfico não é um método acurado para a determinação do número de fetos entre 45 e 48 dias de gestação e que o tempo ideal para realizar o exame é entre 54 e 57 dias de gestação, momento em que o crânio do feto é totalmente visível na radiografia.

Palavras-chave: Contagem fetal, cão, exame radiográfico, gestação

1 Discentes, Programa de Pós-graduação em Ciências Veterinárias, Universidade Federal do Paraná, PPGCV/UFPR, Curitiba, PR. Brasil.E-mail: daniapag@yahoo.com.br; elainegil07@gmail.com; amaliaturner@uol.com.br

2 Discente de Graduação, UFPR, Curitiba, PR, Brasil. E-mail: mari_rompk@hotmail.com

3 Prof ${ }^{a}$, UFPR, Curitiba, PR, Brasil. E-mail: tilde@ufpr.br

Author for correspondence 


\section{Introduction}

There have been significant advances in recent years in the use of diagnostic imaging to evaluate pregnant bitches. Ultrasound is the modality of choice for pregnancy diagnosis and assessment of fetal viability in small animals (DAVIDSON; BAKER, 2009). However, ultrasound has poor accuracy in determining the number of intrauterine fetuses (ROOT; SPAULDING, 1994). Abdominal radiography provides a more accurate assessment of fetal numbers and is thus still the main technique used for counting fetuses (TOAL et al., 1986; RENDANO, 1983; RENDANO et al., 1984.; LOPATE, 2008). Once fetal skulls have mineralized they can be counted on radiographs and provide a precise method of determining fetal numbers (TOAL et al., 1986; GRADIAL et al., 2000).

There is disagreement in the literature on the optimal gestational time at which to determine radiographically the fetal number in the bitches. Some studies suggest between 43 and 54 days (WANKE; GOBELLO, 2006), whilst others suggest from 45 days onwards (LINDE-FORSBERG, 2005). Some studies advocate that radiographs should be taken once there is good fetal bone mineralization, which occurs after 51 days (TOAL et al., 1986).

Sirsat et al. (2008) reported that between 45 and 50 days radiographic interpretation can be complicated by poor fetal mineralization. It has also been reported that overlapping fetal structures hinder accurate identification of components of the skeleton and can prevent accurate counting of fetal numbers (JOHNSTON et al., 2001).

Any errors made in the radiological assessment of fetal numbers can cause the owner uncertainty and frustration. Thus, the questions to be answered by this study were: (1) How accurate are digital radiographs for fetal counting; (2) What is the optimal time to perform radiography for fetal counting; and (3) Which factors hinder interpretation of radiographs. The objective of this study was to compare the accuracy of fetal counting from abdominal radiographs at two gestational stages and to analyze the factors complicating this determination.

\section{Materials and Methods}

This was a longitudinal, observational, prospectivestudycomparingabdominal radiographic examination in bitches at two gestational stages. All procedures were conducted in accordance with the Animal Use Committee Guidelines. Fifty eight abdominal radiographs (right lateral, left lateral and ventrodorsal projections) were performed in thirty-eight pregnant bitches comprising a variety of breeds, ages and body-weights were randomly selected from the clinical caseload of a veterinary hospital. All owners consented to radiographic procedures.

The radiographs were divided according to the time of gestation at which they had been taken. Group I ( $n=29)$ included bitches between 45 and 48 days of gestation, and the Group II ( $\mathrm{n}=29)$ included bitches between 54 and 57 days of gestation. Some bitches were radiographed twice, and appear in both groups $(\mathrm{n}=20)$, and some only once $(\mathrm{n}=18)$. The gestational time of the bitches was determined according to copulation or insemination date (when known), or was estimated by sonographic evaluation of fetal organogenesis as defined by England et al. (2003), and was confirmed retrospectively from delivery dates. Owners recorded the number of puppies born and this value was used for the statistical analysis.

Radiographic technique and positioning were as recommended by Graham et al. (2007) using a Medicor Budapest X-ray machine (NeoDiagnomax, Budapest, Hungary). All radiographs were acquired using a digital radiography system (CR-30-X, Agfa Health Care, Brussels, Belgium) using a specific filter for evaluation of the abdominal cavity. The radiographic images were converted to a portable document format (PDF), coded, and then sent to two veterinarians, both with over seven years of radiology training and certification by the 
Brazilian College of Veterinary Radiology. These veterinarians were unaware of the gestational age of the fetuses. During assessment, observers noted the number of fetuses visualized in the three projections and what difficulties (if any) were encountered in counting the fetuses. The number of fetuses present was determined by counting fetal skulls.

For statistical analysis, a descriptive study was conducted. The kappa coefficient was used to evaluate interobserver agreement and Pearson's correlation was used to compare the number of pups born and the fetal number observed on radiographs. The values of the Kappa index were classified according to work by Landis and Kock (1977) and Pearson's correlation values were classified according to work by Freedman et al. (2007). The statistical analyzes were performed using "R" software, free distribution version 3.0.2 i386, in "irr" and "lattice" package.

\section{Results}

The breeds represented in the study were English Bulldog (4), Pug (4), mixed-breed (4), Brazilian Terrier (3), Schnauzer (3), French Bulldog (2), Siberian Husky (2), Lhasa Apso (2), Yorkshire Terrier (1), Beagle (1), Boxer (1), Chinese Crested (1), Dachshund (1), German Shepherd (1), Doberman (1), Pitbull (1), Poodle (1) and Rottweiler (1). Ages ranged from 1 to 7 years, with a mean of 3 years. The majority of bitches in the study whelped between 3 and 5 puppies.

Table 1 shows the number and percentage of correct and incorrect fetal counts, (with reference to the number of puppies born), in Groups I and II by each observer. Note that most of the errors in the Group I were due to underestimation of fetal number; the number of correct counts increased with fetal maturity, independent of the observer.

Table 1. Number and percentage of correct and incorrect assessments of number of fetuses compared to number of pups born and classification of errors.

\begin{tabular}{lccccccccc}
\hline \multirow{2}{*}{ Result } & \multicolumn{4}{c}{ Observer1 } & \multicolumn{4}{c}{ Observer 2 } \\
\cline { 2 - 9 } & Group I & \% & Group II & \% & Group I & \% & Group II & \% \\
\hline Correct & 4 & 13.79 & 20 & 68.97 & 7 & 24.14 & 17 & 58.62 \\
Errors & 25 & 86.21 & 9 & 31.03 & 21 & 75.86 & 12 & 41.38 \\
\hline Classification of errors & & & & & & & & \\
- count over estimated number & 1 & 3.45 & 3 & 10.34 & 4 & 13.79 & 5 & 17.24 \\
- count underestimated number & 24 & 82.76 & 6 & 20.69 & 17 & 62.07 & 7 & 24.14 \\
\hline
\end{tabular}

The analysis of interobserver agreement using the Kappa index showed that there was only reasonable agreement between observers for Group I. This improved for Group II and agreement was substantial, as seen in Table 2. Table 3 shows the estimated value of Pearson's coefficient for Group I, in which correlation between observer 1 and 2 and the number of puppies born was positive, but weak.
For Group II, the correlation values were significant and positive.

The main difficulties reported by observers were insufficient fetal mineralization in Group I, and challenges counting in bitches with large numbers of fetuses in Group II as shown in Table 4. Figure 1 and 2 show an abdominal radiograph from a bitch in Group I and Group II, respectively. 
Table 2. Kappa Index, percentage agreement and error rate between observers 1 and 2, in both periods reading 58 abdominal radiographs.

\begin{tabular}{lccc}
\hline \multirow{2}{*}{ Group } & \multicolumn{3}{c}{ Agreement between observers } \\
\cline { 2 - 4 } & Kappa concordance & \% concordance & Error rate (\%) \\
\hline Group I & 0.385 & 38.5 & 61.5 \\
Group II & 0.673 & 67.3 & 32.7 \\
\hline
\end{tabular}

Table 3. Pearson correlation index between the observer and the number of pups born.

\begin{tabular}{lccc}
\hline \multirow{2}{*}{ Group I } & Pearson correlation & \multicolumn{2}{c}{ Confidence interval of 95\% } \\
\cline { 3 - 3 } & (parametric) & Lower limit & Upper limit \\
Observer 1 x Pups & 0.3326 & -0.0385 & 0.6232 \\
Observer 2 x Pups & 0.4107 & 0.0521 & 0.6756 \\
Group II & Pearson correlation & Confidence interval of 95\% \\
Observer 1 x Pups & (parametric) & Lower limit & Upper limit \\
Observer 2 x Pups & 0.8674 & 0.7344 & 0.9363 \\
\hline
\end{tabular}

Table 4. Number of abdominal radiographs in which there were difficulties described by observers during review in the different stages of gestation.

\begin{tabular}{lcccc}
\hline \multicolumn{1}{c}{ Difficulties } & \multicolumn{2}{c}{ Observer 1 } & \multicolumn{2}{c}{ Observer 2 } \\
\cline { 2 - 5 } \multicolumn{1}{c}{} & Group I & Group II & Group I & Group II \\
\hline Insufficient fetal mineralization & 20 & 2 & 27 & 2 \\
Large number of fetuses & - & 3 & - & 3 \\
Obese dam & 1 & - & 1 & - \\
Gastric distension due to feeding & - & - & - & 1 \\
Total & 21 & 5 & 28 & 6 \\
\hline
\end{tabular}

Figure 1. Shows abdominal radiographs from Group I (A) Left lateral radiographic projection; (B) Right lateral radiographic projection. (C) Ventrodorsal radiographic projection. Note the difficulty in counting fetus due to insufficient fetal mineralization.
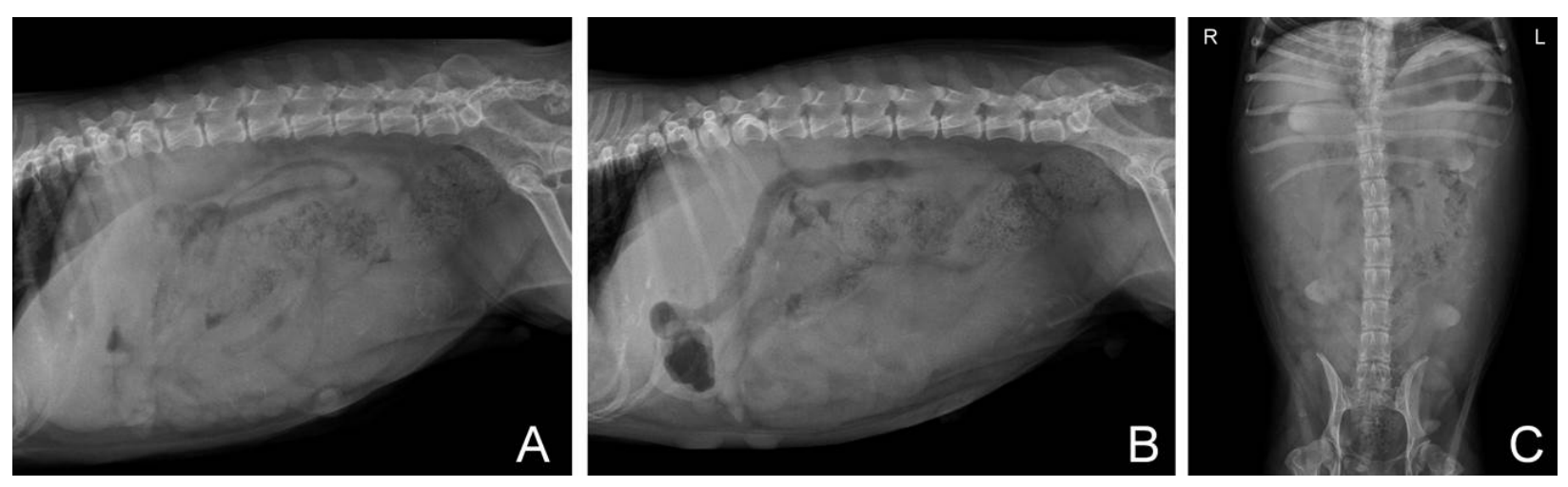
Figure 2. Shows abdominal radiographs from bitched in Group II (A) Left lateral radiographic projection showing 7 fetuses; (B) Right lateral radiographic projection showing 5 fetuses. (C) Ventrodorsal radiographic projection showing 5 fetuses.
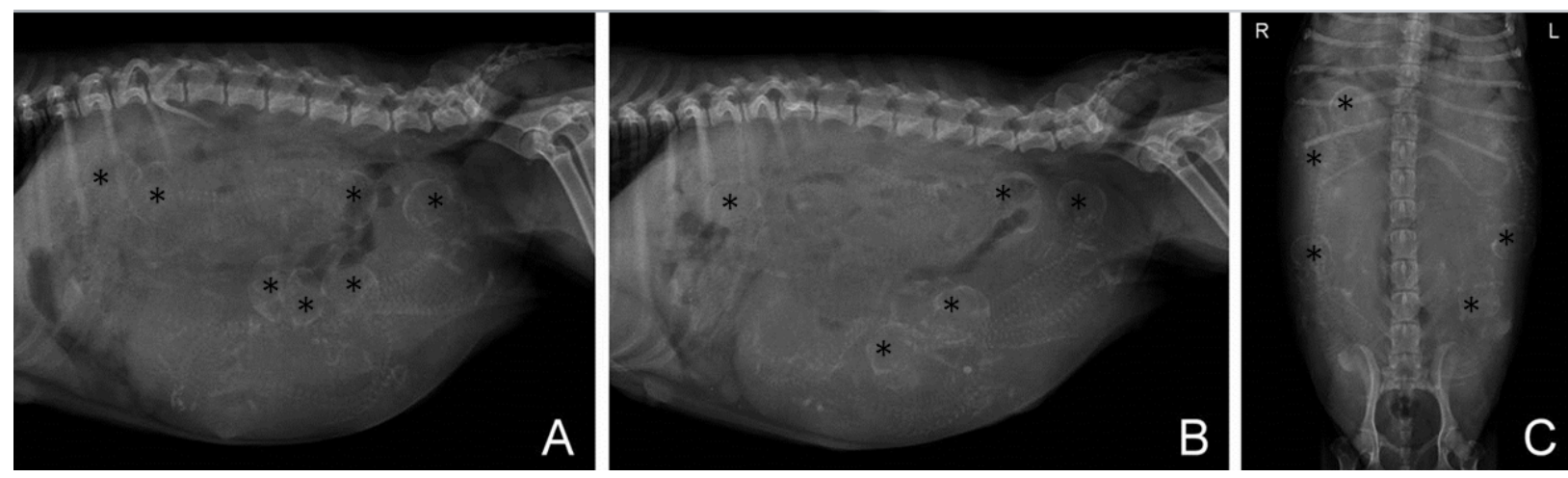

All puppies were born healthy, and no abnormalities due to deleterious effects of ionizing radiation were reported.

\section{Discussion}

Most studies on radiographic assessment of fetal number are outdated (TOAL et al., 1986; RENDANO, 1983; RENDANO et al., 1984) and used conventional radiographic techniques. Abdominal radiography as a method of counting fetuses in bitches should be used with caution, since it is not $100 \%$ accurate. It is, however, the technique of choice compared to ultrasound examination in which accuracy is low. The examination is best performed after fetuses are 54 days of age, since the absence of significant fetal mineralization before this time is the main limiting factor in fetal counting. Radiographic examination is not indicated between 45 and 48 days of gestation when poor fetal mineralization significantly reduces accuracy (TOAL et al., 1986; RENDANO, 1983). This study shows that the best time to perform radiographic examination is between 54 and 57 days of gestation, in which clear visualization of the fetal skull is possible, using digital radiography (MEYERLINDENBERG et al., 2008). When radiographic examination is performed between 45 and 48 days of gestation, it is difficult to count fetal skulls and error rates are high.
There was significant underestimation of the number of fetuses between 45 and 48 days of gestation (Group I) and conversely an overestimation of fetal numbers between 54 and 57 days of gestation. The errors resulting in overestimation of fetal numbers between 54 and 57 days (Group II) were probably due to a large number of fetuses in some bitches causing overlapping radiographic images that made it challenging for the radiologists to count individual fetal skulls. Therefore, even with fully mineralized skulls, accurate counting can be hampered by a large numbers of fetuses. It is interesting to note that underestimation errors were more frequent and this is probably because, when faced with uncertainty, the observer prefers to err on the side of undercounting.

There was a reasonable inter-observer agreement in Group I and substantial agreement in Group II. This confirms that as fetuses mature and mineralization increases accuracy improves. Since only certified radiologists were chosen for this study, we cannot determine whether observer experience influenced this interpretation.

The use of abdominal radiography for counting fetal numbers between 45 and 48 days of gestation is inaccurate as there is little contrast between the fetal tissues and the adjacent soft tissues (fetal liquids and the soft tissues of the uterus). Poor mineralization can generate positive and/or false negative results, 
and is probably the main complicating factor for accurate radiographic evaluation, as reported by observers (TOAL et al., 1986; RENDANO, 1983; LOPATE, 2008). Other factors that can hinder accurate counting are large numbers of fetuses, obese dams, and gastric distension post-feeding. Toal et al. (1986) performed radiography in 15 pregnant bitches in the third trimester, missed the counting of fetuses in one bitch, and also reported that gastrointestinal tract complicates the fetus count due to ingesta within the gastrointestinal tract.

The results obtained after the correlation analysis confirmed that between 54 and 57 days (Group II) there is greater agreement between the number of fetuses counted by observers and the number of puppies born. The Pearson's correlation was weak at gestational ages between 45 and 48 days (Group I), showing that the optimal time to perform accurate radiographic fetal counts is between the gestational ages of 54 and 57 days. Even between 54 and 57 days of gestation (Group II) there is a $30 \%$ estimated error rate in estimated fetal number. This is due to a combination of factors and may be compounded by human cognitive bias errors (GUNDERMAN, 2009), the mental or physical fatigue of the radiologist, and observer variability (JOHNSON; KLINE, 2010; TUDOR et al., 2007). These factors may be independent of the training and experience of the radiologist.

This study had limitations. The influence of physical characteristics/breed differences was not assessed. It is likely that breed characteristics, such as higher fat accumulation, may be a complicating factor for radiographic assessment. Additionally, only two periods of gestation were compared; the gestation stage between 48 and 54 days was not evaluated.

This study was performed using three radiographic projections to minimize potential differences in radiographic interpretation. There have been no reports giving clear guidance on the number of radiographic projections necessary for counting fetuses. Some reports suggest that a single ventrodorsal projection is sufficient to compare the size of the pelvic canal to the fetal skull but do not comment on the optimal projections for fetal counting (TOAL et al., 1986; RENDANO et al., 1984). We believe that more radiographic projections assist assessment and therefore improve accuracy. However, this is purely speculative as the effect of the number of projections on the accuracy of the fetal count was not tested. Owing to the deleterious effects of ionizing radiation, consideration must be given to the risks and benefits of performing multiple radiographs for fetal counting.

\section{Conclusion}

The best time to perform the radiographic examination for the fetal count is after 54 days of gestation even when performed using computed radiology (CR). The best quality $\mathrm{CR}$ equipment for the definition of bone structures may still result in errors of up to $30 \%$ due to overlap when there are multiple fetuses.

\section{Acknowledgments}

We would like to thank the owners who agreed to help in this study and Eliane de Fátima Coimbra for statistical analysis.

\section{References}

DAVIDSON, A. P.; BAKER, T. W. Reproductive ultrasound of the bitch and queen. Topics in Companion Animal Medicine, Maryland, v. 24, n. 2, p. 55-63, 2009.

ENGLAND, C. G. W.; YEGER, A. E.; CONCANNON, $\mathrm{P}$. W. Ultrasound imaging of the reproductive tract of the bitch. In: CONCANNON, P. W.; ENGLAND, C. G. W.; VERSTEGEN, J.; LINDE-FORSBERG, C. (Ed.). Recent advances in small animal reproduction. Ithaca: International Veterinary Information Service, 2003. p. 104-110. Available at: <http://www.ivis.org>. Accessed at: 2 aug. 2013.

FREEDMAN, D.; PISANI, R.; PURVES, R. Statistics. $4^{\text {th }}$ ed. New York: W. W. Norton \& Co, 2007. 720 p. 
GRADIAL, C. M.; YEAGER, A. E.; CONCANNON, P. W. Pregnancy diagnosis in the bitch. In: BONAGURA, J. D. Kirk's current veterinary therapy XIII small animal practice. Philadelphia: W. B. Saunders Company, 2000. p. 918-923.

GRAHAM, J. P.; BERRY, C. R.; THRALL, D. E. Technical issues and interpretation principles relating to the canine and feline abdomen. In: THRALL, D. E. Textbook of veterinary diagnostic radiology. $5^{\text {th }}$ ed. St. Louis: Saunders Elsevier, 2007. p. 626-644.

GUNDERMAN, R. B. Biases in radiologic reasoning. American Journal of Roetegenology, Springfield, v. 192, n. 3, p. 561-564, 2009.

JOHNSON, J.; KLINE, J. A. Intraobserver and interobserver agreement of the interpretation of pediatric chest radiographs. Emergency Radiology, New York, v. 17 , n. 4, p. 285-290, 2010.

JOHNSTON, S. D.; ROOT KUSTRITZ, M. V.; OLSON, P. N. Canine pregnancy. Canine and feline theriogenology. Philidelphia: WB Saunders, 2001. 592 p.

LANDIS, J. R.; KOCH, G. G. The measurement of observer agreement for categorical data. Biometrics, Arlington, v. 33, n. 1, p. 159-174, 1977.

LINDE-FORSBERG, C. Abnormalities in pregnancy, parturition and the periparturient period. In: ETTINGER, S. J.; FELDMAN, E. C. Textbook of veterinary internal medicine. $6^{\text {th }}$ ed. St. Louis: Elsevier Saunders, 2005. p. 1655-1667.

LOPATE, C. Estimation of gestational age and assessment of canine fetal maturation using radiology and ultrasonography: a review. Theriogenology, Philadelphia, v. 70, n. 3, p. 397-402, 2008.
MEYER-LINDENBERG， A.; EBERMAIER， C.; WOLVEKAMP, P.; TELLHELM, B.; MEUTSTEGE, F. J.; LANG, J.; HARTUNG, K.; FEHR, M.; NOLTE, I. Comparative evaluation of six different body regions of the dog using analog and digital radiography. Berl Munch Tierarztl Wochenschr, Berlin, v. 121, n. 5-6, p. 216-227, 2008.

RENDANO, V. T. Radiographic evaluation of fetal development in the bitch and fetal death in the bitch and queen. In: KIRK, R. W. Current veterinary therapy. Philadelphia: WB Saunders Co., 1983. v. VIII, 1440 p.

RENDANO, V. T.; LEIN, D. H.; CONCANNON, P. W. Radiographic evaluation of prenatal development in the Beagle: correlation with time of breeding, LH release, and parturition. Veterinary Radiology, Oxford, v. 25, n. 3, p. 132-141, 1984.

ROOT, C. R.; SPAULDING, K. A. Diagnostic imaging companion animal theriogenology. Seminars in Veterinary Medicine and Surgery, Orlando, v. 9, n. 1, p. 7-27, 1994.

SIRSAT, P. R.; RAGHUWANSHI, D. S.; UPADHYE, S. V.; DHAKATE, M. S.; KHAN, L. A.; TAKSANDE, P. E. Radiographic diagnosis of canine pregnancy. Intas Polivet, Gujarat, v. 9, n. 2, p. 376-377, 2008.

TOAL, R. L.; WALKER, M. A.; HENRY, G. A. A comparison of real-time ultrasound, palpation and radiography in pregnancy detection and litter size determination in the bitch. Veterinary Radiology, Oxford, v. 27, n. 4, p. 102-108, 1986.

TUDOR, G. R.; FINLAY, D.; TAUB, N. An assessment of interobserver agreement and accuracy when reporting plain radiographs. Clinical Radiology, Oxford, v. 52, n. 3, p. 235-38, 1997.

WANKE, M. M.; GOBELLO, C. Reproduccion en caninos y felinos domesticos. Buenos Aires: InterMedica, 2006. 328 p. 
